\title{
Immunochemical and Protein-Chemical Studies of Class I Fructose 1,6-Diphosphate Aldolases from Staphylococci
}

\author{
STEPHAN FISCHER, ${ }^{1 \dagger}$ AKIRA TSUGITA, ${ }^{1 *}$ BIRGIT KREUTZ, ${ }^{2}$ AND KARL HEINZ SCHLEIFER ${ }^{2}$ \\ European Molecular Biology Laboratory, D-6900 Heidelberg, ${ }^{1}$ and Department of Microbiology, Technical \\ University of Munich, D-8000 Munich, ${ }^{2}$ Federal Republic of Germany
}

\begin{abstract}
The class I fructose 1,6-diphosphate aldolases of five staphylococcal strains were purified and characterized. All of these enzymes could be renatured to active structures after exposure to a temperature of $90^{\circ} \mathrm{C}$. By using antisera against the enzymes, we measured the immunological cross-reactions by microcomplement fixation and activity inhibition. The amino acid compositions of the purified proteins were determined and compared. Our results provide further insight into the phylogenetical relationships among the staphylococcal species studied. Staphylococcus capitis, Staphylococcus epidermidis, Staphylococcus warneri, and Staphylococcus haemolyticus form a group of highly related species. Staphylococcus aureus was shown to be closely related to this group, whereas all of the other staphylococcal species showed distant relationships. Staphylococcus sciuri subsp. sciuri and $S$. sciuri subsp. lentus occupy a rather isolated position within the genus Staphylococcus and are related to each other at the species level.
\end{abstract}

The fructose 1,6-diphosphate (FDP) aldolases which are usually found in bacteria and fungi are class II enzymes (31). These enzymes need a divalent metal ion for activity and are inhibited by chelating agents. In contrast, class I aldolases have been found in most staphylococci (9) and a few other bacteria $(13,20,21,35)$. Class I aldolases can be irreversibly inhibited by dihydroxyacetone phosphate in the presence of sodium borohydride (12). The class I FDP aldolases from staphylococci and peptococci appear to be similar in enzymatic kinetics and molecular weight. The presence of class I aldolases in staphylococci is a useful property for distinguishing these organisms from other members of the family Micrococcaceae (9). Both class II aldolase activity and class I aldolase activity have been found in Staphylococcus hyicus and Staphylococcus intermedius strains, but only a class II enzyme occurs in Staphylococcus caseolyticus (6). This difference provides a simple method for classifying these staphylococci within the genus. Furthermore, the phylogenetic relationships of staphylococci have been determined by deoxyribonucleic acid (DNA)-DNA $(15,17,24,29,32)$ and DNA-ribonucleic acid (RNA) homology (14) studies, as well as by comparing $16 \mathrm{~S}$ ribosomal RNAs (23) and immunological cross-reactions of catalases $(30,32)$. In the present study we used the following two essentially different methods to reveal the phylo-

$\dagger$ Present address: Department of Biochemistry, University of Düsseldorf, D-4000 Düsseldorf, Federal Republic of Germany. genetic relationships among certain staphylococci: (i) immunological cross-reactivity and (ii) homology of amino acid compositions. One gene product was used for both methods (namely, the class I aldolases).

\section{MATERIALS AND METHODS}

Cultivation and preparation of crude extracts. The strains used in this study are the type strains of the species examined and were obtained from the American Type Culture Collection (ATCC), Rockville, Md., the Czechoslovak Culture Collection (CCM), Brno, Czechoslovakia, the National Collection of Type Cultures (NCTC), London, United Kingdom, and the Deutsche Sammlung von Mikroorganismen (DSM), Göttingen, Federal Republic of Germany. All staphylococci were cultured at $37^{\circ} \mathrm{C}$ in a medium containing $1 \%$ glucose, $0.5 \%$ yeast extract, $0.8 \% \mathrm{NaCl}$, and 0.05 $\mathrm{M}$ sodium phosphate buffer ( $\mathrm{pH} 7.5$ ). For enzyme preparations, the cultures were grown in aerated 20 liter flasks until the end of the logarithmic phase. The cells were harvested by centrifugation, and the pellets were washed with water and then stored at $-20^{\circ} \mathrm{C}$ (about $50 \mathrm{~g}$ [wet weight]). Crude extracts were prepared as previously described (8).

Aldolase purification. The purification method used was modified from the method described previously (8). All steps were carried out at $4^{\circ} \mathrm{C}$. Solid ammonium sulfate was added stepwise at different $\mathrm{pH}$ values (Table 1). After each step, the precipitate was removed by centrifugation at $48,000 \times g$ for $30 \mathrm{~min}$. The precipitate from the last step was collected and dissolved in $0.06 \mathrm{M}$ tris(hydroxymethyl)aminomethane hydrochloride buffer ( $\mathrm{pH} 7.5$ ) (standard buffer). The $\mathrm{pH}$ of the solution was adjusted to $\mathrm{pH} 4.3$ with acetic acid, and the preparation was stirred for $2 \mathrm{~h}$ and clarified by centrifugation. The resulting supernatant 
TABLE 1. Purification of the class I aldolase from $S$. epidermidis ATCC $14990^{\mathrm{T}}$

\begin{tabular}{|c|c|c|c|c|c|c|}
\hline Step & $\begin{array}{l}\text { Vol } \\
(\mathrm{ml})\end{array}$ & $\begin{array}{l}\text { Total } \\
\text { activity } \\
\text { (U) }^{a}\end{array}$ & $\begin{array}{l}\text { Total } \\
\text { protein } \\
(\mathrm{mg})^{b}\end{array}$ & $\mathrm{U} / \mathrm{mg}$ & $\begin{array}{l}\text { Purification } \\
\quad(- \text { fold })\end{array}$ & $\begin{array}{l}\text { Recovery } \\
(\%)\end{array}$ \\
\hline $\begin{array}{l}\text { Crude extract } \\
\left(\mathrm{NH}_{4}\right) \mathrm{SO}_{4} \text { precipi- } \\
\text { tation steps }\end{array}$ & 306 & 612 & 5,202 & 0.12 & 0 & 100 \\
\hline $40 \%(\mathrm{pH} 7.5)$ & $335^{c}$ & 502 & 3,015 & 0.17 & 1.4 & 82 \\
\hline $60 \%(\mathrm{pH} 7.5)$ & $356^{c}$ & 496 & 2,680 & 0.19 & 1.6 & 81 \\
\hline $80 \%(\div$ H 7.5) & $380^{c}$ & 462 & 1,440 & 0.32 & 2.7 & 75.5 \\
\hline $100 \%(1$ H 5.0$)$ & $94^{d}$ & 430 & 940 & 0.46 & 3.8 & 70.3 \\
\hline \multicolumn{7}{|l|}{ Acid treatment } \\
\hline $\mathrm{pH} 4.3$ & $184^{c}$ & 429 & 353 & 1.2 & 10 & 70.1 \\
\hline pH 3.5 & $30^{d}$ & 425 & 246 & 1.73 & 14.4 & 69.4 \\
\hline $\begin{array}{l}\text { Diethylamino- } \\
\text { ethyl-Sephadex } \\
\text { A-25 chromatog- } \\
\text { raphy }\end{array}$ & 130 & 320 & 71.2 & 4.5 & 37.5 & 52.3 \\
\hline $\begin{array}{l}\text { Sephadex G-100 } \\
\text { chromatography }\end{array}$ & 17.4 & 310 & 21.4 & 14.5 & 120.7 & 51.0 \\
\hline
\end{tabular}

${ }^{a}$ One unit was the amount that oxidized $1 \mu \mathrm{mol}$ of reduced nicotinamide adenine dinucleotide per min.

${ }^{b}$ Protein was determined by the method of Lowry et al. (22).

$c$ Supernatant.

${ }^{d}$ Precipitate.

was adjusted to $\mathrm{pH} 3.5$ with $\mathrm{HCl}$. After $4 \mathrm{~h}$, the precipitated protein was collected by centrifugation at $80,000 \times g$ for $1 \mathrm{~h}$. The resulting sediment was dissolved in $0.6 \mathrm{M}$ tris(hydroxymethyl)aminomethane hydrochloride buffer ( $\mathrm{pH} 7.5$ ) and dialyzed against standard buffer.

The dialysate was applied to a diethylaminoethylSephadex A-25 column $(2.5$ by $25 \mathrm{~cm})$, which was equilibrated in standard buffer, and then washed consecutively with $100 \mathrm{ml}$ of standard buffer and $100 \mathrm{ml}$ of standard buffer containing $0.1 \mathrm{M} \mathrm{NaCl}$. Elution was carried out with a linear gradient prepared from $200 \mathrm{ml}$ of $0.1 \mathrm{M} \mathrm{NaCl}$ and $200 \mathrm{ml}$ of $0.5 \mathrm{M} \mathrm{NaCl}$ in standard buffer. The eluant was monitored at $278 \mathrm{~nm}$ for protein and enzymatic activities. The fractions containing activity were collected, and the protein was precipitated by adding $564 \mathrm{~g}$ of ammonium sulfate ( $\mathrm{pH} \mathrm{4.0)}$ per liter. The precipitate was dissolved in a minimal volume of $0.6 \mathrm{M}$ tris(hydroxymethyl)aminomethane hydrochloride buffer ( $\mathrm{pH} 7.5 ; 2$ to $3 \mathrm{ml}$ ) and was applied to a Sephadex G-100 (superfine) column (1.6 by 200 $\mathrm{cm}$ ). Elution was carried out with standard buffer containing $1 \mathrm{M} \mathrm{NaCl}$ and was monitored as described above and also by sodium dodecyl sulfate (SDS) slab gel electrophoresis (see below). The homogeneous fractions were pooled and stored at $-20^{\circ} \mathrm{C}$.

SDS gel electrophoresis. SDS-polyacrylamide slab gel electrophoresis was carried out by the method of Laemmli (18). The molecular weights of the proteins were determined by the method of Weber and Osborne (37), using a $3 \%$ stacking gel and a $10 \%$ separation gel. Bovine serum albumin (molecular weight, 67,000), ovalbumin $(45,000)$, the $\beta$-subunit of the Escherichia coli RNA polymerase $(39,000)$, and soybean trypsin inhibitor (21.500) were used as standards.

Aldolase activity assay. Aldolase activity was determined spectrophotometrically by the method of Penhoe et al. (27).

Temperature stability assay. Portions $(5 \mu \mathrm{g})$ of puri- fied enzyme in $200 \mu$ l of standard buffer were incubated in sealed glass tubes for $10 \mathrm{~min}$ at $90^{\circ} \mathrm{C}$. After slow cooling, the activity remaining was determined by a spectrophotometric assay.

Determination of immunological cross-reactions. Antisera against the staphylococcal aldolases were prepared as described previously (30). Cross-reactions of aldolases with antisera were determined by a micro-

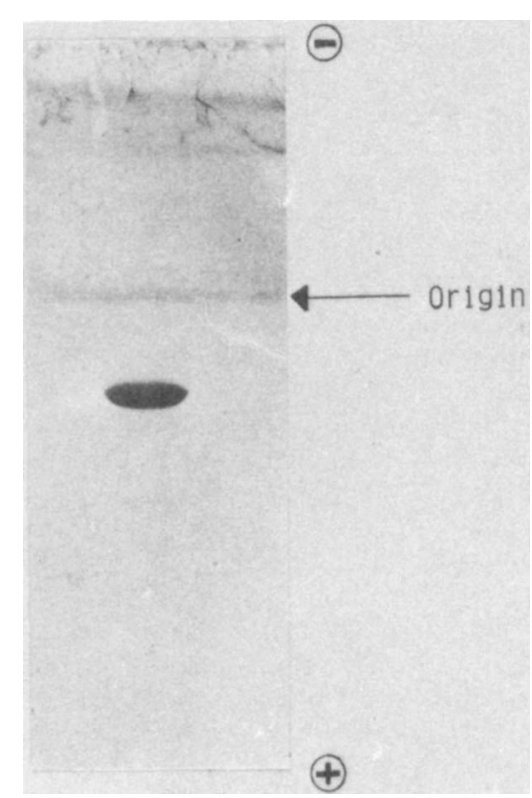

FIG. 1. SDS electrophoresis of purified $S$. epidermidis aldolase. A 40- $\mu \mathrm{g}$ portion of protein was applied and stained with Coomassie brilliant blye. 
TABLE 2. Molecular weights of purified class I aldolases, as determined by SDS slab gel electrophoresis

\begin{tabular}{lcc}
\hline \multicolumn{1}{c}{ Strain } & $\begin{array}{c}\text { Mol wt of } \\
\text { class I } \\
\text { aldolase }\end{array}$ & $\begin{array}{c}\text { Remaining } \\
\text { activity } \\
(\%)^{a}\end{array}$ \\
\hline S. aureus ATCC $12600^{\mathrm{T}}$ & 35,000 & 98 \\
S. epidermidis ATCC $14990^{\mathrm{T}}$ & 34,500 & 95 \\
S. haemolyticus DSM 20263 & 34,500 & 98 \\
S. xylosus DSM $20266^{\mathrm{T}}$ & 35,500 & 50 \\
S. sciuri subsp. sciuri ATCC & 35,000 & 92 \\
$29062^{\mathrm{T}}$ & & \\
\hline
\end{tabular}

${ }^{a}$ After heat inactivation of class I aldolases.

complement fixation method (2), as described previously for catalase antiserum $(30,32)$. In the microcomplement fixation assay, the antiserum concentration which gives optimal complement fixation with the homologous protein is determined. When a heterologous protein is used, a higher concentration of antiserum is necessary to achieve the same rate of complement fixation observed in the homologous system. The factor by which the antiserum concentration has to be increased is called the index of dissimilarity. The immunological distance (ID) used in this study is defined as 100 times the logarithm of the index of dissimilarity. Inhibition of an aldolase activity by an antiserum was determined by incubating $20 \mu \mathrm{l}$ of the aldolase ( 0.1 to $0.2 \mathrm{U}$ of activity) with $100 \mu \mathrm{l}$ of the antiserum. This amount corresponds to a 40 -fold excess of antiserum, which affords maximum inhibition of the activity of the homologous enzyme.

Determination and comparison of amino acid compositions. Each protein was dialyzed against $0.1 \mathrm{M}$ pyridine acetate buffer ( $\mathrm{pH} 7.0$ ). A sample ( 5 to $10 \mu \mathrm{g}$ ) was dried and then dissolved in a mixture of $\mathrm{HCl}$ and trifluoroacetic acid (2:1) containing $0.005 \%$ freshly distilled phenol. After hydrolysis at $166^{\circ} \mathrm{C}$ for 25 and $50 \mathrm{~min}$, the amino acids were determined by using a Durrum model D-500 amino acid analyzer. The value for each amino acid was calculated as described by Tsugita and Scheffler (36). Tryptophan was determined by the method of Pajot (26), and cysteine was determined after performic acid oxidation of the protein (33).

The sequence homology of proteins was calculated by using the amino acid compositions to obtain a divergence matrix by the method of Cornish-Bowden (4), where the divergence index $\left(S \Delta_{n}\right)$ is defined as follows: $S \Delta_{n}=1 / 2 \Sigma\left(n_{i A}-n_{i B}\right)^{2}$, where $n_{i A}$ is the number of amino acid $i$ in protein $A$ and $n_{i B}$ is the number of the corresponding amino acid in protein $B$. $S \Delta_{n}$ divided by one-half the total number of amino acids in proteins $A$ and $B$ gives the composition divergence index $\left(S \Delta_{n} / N\right)$, which is used in this study. The coefficient of variation is around $38 \% . S \Delta_{n} / N$ values lower than 0.42 indicate similarity and are significant at a $95 \%$ level of confidence. $S \Delta_{n} / N$ values between 0.42 and 0.93 indicate possible similarity, whereas values higher than 0.93 indicate no similarity.

\section{RESULTS}

Purification. The FDP aldolases of the type strains of five staphylococcal species were puri- fied. Recovery was about twofold higher than that obtained with the method described previously for the isolation of the FDP aldolase from Staphylococcus aureus (8). The details of purification of the enzyme from Staphylococcus epidermidis are shown in Table 1 . The homogeneity of the protein, as determined by SDS gel electrophoresis, is shown in Fig. 1. Elution from the Sephadex G-100 chromatographic column and relative mobilities during SDS gel electrophoresis were used to determine the molecular weights of the purified proteins. The class I aldolases from the staphylococci studied were shown to be monomers with molecular weights between 33,000 and 35,000 (Table 2).

Temperature stability. The five purified class I aldolases renatured to active conformations after incubation at $90^{\circ} \mathrm{C}$ and slow cooling (Table 2 ). The addition of $0.004 \mathrm{M} \beta$-mercaptoethanol did not affect renaturation.

Immunological cross-reactions. Antisera were prepared against the purified enzymes from the type strains of $S$. aureus, $S$. epidermidis, and Staphylococcus sciuri subsp. sciuri. Using antiserum against the aldolase from $S$. aureus we analyzed the inhibition of enzyme activity with aldolases from several staphylococci (Table 3). After crude extracts of $S$. aureus were incubated with an excess of anti-S. aureus aldolase serum, an $80 \%$ decrease in activity was observed. If the crude extracts from other strains were treated in the same way, inhibitory activity was considerably reduced. Even though the amount of inhibition varied in different experiments, the relative values were similar in any one assay. A crude extract from Micrococcus luteus having a class II aldolase (9) was used as a negative control for this inhibition assay.

TABLE 3. Inhibition of aldolase activity by serum against $S$. aureus aldolase ${ }^{a}$

\begin{tabular}{|c|c|}
\hline Strain & Inhibition (\%) \\
\hline S. aureus ATCC $12600^{\mathrm{T}}$ & $70 \pm 10$ \\
\hline S. epidermidis ATCC $14990^{\mathrm{T}}$ & $60 \pm 10$ \\
\hline S. warneri ATCC $27836^{\mathrm{T}}$ & $60 \pm 10$ \\
\hline S. haemolyticus DSM $20263^{\mathrm{T}}$ & $60 \pm 10$ \\
\hline S. hominis ATCC $27844^{\mathrm{T}}$ & $60 \pm 10$ \\
\hline S. capitis ATCC $27840^{\mathrm{T}}$ & $60 \pm 10$ \\
\hline S. xylosus DSM $20266^{\mathrm{T}}$ & $30 \pm 10$ \\
\hline $\begin{array}{l}\text { Staphylococcus saprophyticus } \\
\text { CCM } 883^{\mathrm{T}}\end{array}$ & $30 \pm 10$ \\
\hline $\begin{array}{l}\text { S. sciuri subsp. sciuri ATCC } \\
29062^{\mathrm{T}}\end{array}$ & $15 \pm 5$ \\
\hline S. intermedius CCM $5739^{\mathrm{T}}$ & $5 \pm 5$ \\
\hline M. luteus CCM $169^{\mathrm{T}} b$ & 0 \\
\hline
\end{tabular}

${ }^{a}$ Crude extracts were incubated with the antiserum against $S$. aureus aldolase, and the remaining activity was determined. The values differed in different assays, but the relative inhibition values were the same.

${ }^{b} M$. luteus contains a class II aldolase. 
TABLE 4. Results of microcomplement fixation with antisera against staphylococcal aldolases

\begin{tabular}{|c|c|c|c|}
\hline \multirow[b]{2}{*}{ Strain } & \multicolumn{3}{|c|}{ ID with antiserum against aldolase from: ${ }^{a}$} \\
\hline & $\begin{array}{c}\text { S. aureus } \\
\text { ATCC } 12600^{\mathrm{T}}\end{array}$ & $\begin{array}{l}\text { S. epidermidis } \\
\text { ATCC } 14990^{\mathrm{T}}\end{array}$ & $\begin{array}{l}\text { S. sciuri subsp. } \\
\text { sciuri ATCC } 29062^{\mathrm{I}}\end{array}$ \\
\hline S. aureus ATCC $12600^{\mathrm{T}}$ & 0 & 57 & 131 \\
\hline S. epidermidis ATCC $14990^{\mathrm{T}}$ & 31 & 0 & 111 \\
\hline S. warneri ATCC $27836^{\mathrm{T}}$ & 30 & 28 & $\mathrm{ND}^{b}$ \\
\hline S. capitis ATCC $27840^{\mathrm{T}}$ & 32 & 21 & ND \\
\hline S. hominis ATCC $27844^{\mathrm{T}}$ & 34 & 25 & ND \\
\hline S. haemolyticus DSM $20263^{\mathrm{T}}$ & 36 & 31 & ND \\
\hline S. hyicus subsp. chromogenes NCTC $1462^{\mathrm{T}}$ & 95 & ND & ND \\
\hline S. hyicus subsp. hyicus NCTC $10350^{\mathrm{T}}$ & 97 & 120 & ND \\
\hline S. intermedius CCM $5739^{\mathrm{T}}$ & 110 & 110 & ND \\
\hline Staphylococcus cohnii DSM $20260^{\mathrm{T}}$ & 120 & 119 & ND \\
\hline Staphylococcus saprophyticus CCM $883^{\mathrm{T}}$ & 125 & 110 & ND \\
\hline S. xylosus DSM $20266^{\mathrm{T}}$ & 130 & 113 & 108 \\
\hline S. sciuri subsp. sciuri ATCC $29062^{\mathrm{T}}$ & 135 & 108 & 0 \\
\hline Staphylococcus simulans ATCC $27848^{\mathrm{T}}$ & 139 & 111 & 135 \\
\hline S. sciuri subsp. lentus ATCC $29070^{\mathrm{T}}$ & ND & ND & 67 \\
\hline
\end{tabular}

${ }^{a}$ The deviation was $\pm 5 \%$. For an explanation of ID, see the text.

${ }^{b}$ ND, Not determined.

A more exact quantitation of immunological cross-reactions was obtained by using the microcomplement fixation technique (2). Antisera against the aldolases from $S$. aureus, $S$. epidermidis, and $S$. sciuri were tested with crude extracts from several strains (Table 4). We ob- served no difference in the cross-reactions when either a purified aldolase or a crude extract was used. With antiserum against $S$. aureus aldolase, high degrees of cross-reaction were observed with crude extracts from the following five strains: Staphylococcus warneri, S. epidermidis,

TABLE 5. Amino acid compositions of class I aldolases

\begin{tabular}{|c|c|c|c|c|c|}
\hline \multirow{2}{*}{$\begin{array}{l}\text { Amino } \\
\text { acid }\end{array}$} & \multicolumn{5}{|c|}{ Molar ratio in aldolase of $:^{a}$} \\
\hline & $\begin{array}{c}\text { S. aureus } \\
\text { ATCC } 12600^{\mathrm{T}}\end{array}$ & $\begin{array}{l}\text { S. epidermidis } \\
\text { ATCC } 14990^{\mathrm{T}}\end{array}$ & $\begin{array}{c}\text { S. xylosus } \\
\text { DSM } 20266^{\mathrm{T}}\end{array}$ & $\begin{array}{l}\text { S. haemolyticus } \\
\text { DSM } 20263^{\mathrm{T}}\end{array}$ & $\begin{array}{l}\text { S. sciuri subsp. } \\
\text { sciuri ATCC } 29062^{\mathrm{T}}\end{array}$ \\
\hline Asx & 44 & 48 & 49 & 40 & 40 \\
\hline Thr & 10 & 12 & 13 & 14 & 12 \\
\hline Ser & 20 & 21 & 21 & 24 & 20 \\
\hline Glx & 45 & 41 & 44 & 43 & 55 \\
\hline Pro & 10 & 10 & 10 & 11 & 9 \\
\hline Gly & 23 & 21 & 24 & 23 & 25 \\
\hline Ala & 28 & 25 & 21 & 28 & 25 \\
\hline Val & 22 & 19 & 22 & 26 & 19 \\
\hline Met & 7 & 8 & 7 & 7 & 6 \\
\hline Ile & 14 & 15 & 20 & 14 & 20 \\
\hline Leu & 31 & 29 & 28 & 30 & 26 \\
\hline Tyr & 9 & 9 & 8 & 9 & 10 \\
\hline Phe & 9 & 9 & 11 & 11 & 11 \\
\hline His & 5 & 6 & 6 & 4 & 3 \\
\hline Lys & 28 & 28 & 26 & 27 & 25 \\
\hline Arg & 11 & 10 & 10 & 11 & 10 \\
\hline Cys $^{b}$ & 2 & 2 & 2 & 2 & 2 \\
\hline $\operatorname{Trp}^{c}$ & 0 & 0 & $\mathrm{ND}^{d}$ & ND & ND \\
\hline
\end{tabular}

${ }^{a}$ The results are expressed as the molar ratio of each amino acid residue after acid hydrolysis. The total numbers of amino acid residues in the aldolases were as follows: $S$. aureus ATCC $12600^{\mathrm{T}}, 318 ; S$. epidermidis ATCC $14990^{\mathrm{T}}, 313 ; S$. xylosus DSM 20266 ${ }^{\mathrm{T}}, 322 ; S$. haemolyticus DSM 20263 ${ }^{\mathrm{T}}, 311$; and $S$. sciuri subsp. sciuri ATCC $29062^{\mathrm{T}}, 315$. The molecular weights of the aldolases as determined by SDS gel electrophoresis were as follows: $S$. aureus ATCC $12600^{\mathrm{T}}, 35,000 ;$ S. epidermidis ATCC $14990^{\mathrm{T}}, 34,500 ;$ S. xylosus DSM 20266 ${ }^{\mathrm{T}}, 35,500$; $S$. haemolyticus DSM 20263 ${ }^{\mathrm{T}}, 34,500$; and $S$. sciuri subsp. sciuri ATCC $29062^{\mathrm{T}}, 35,000$.

${ }^{b}$ Cysteine was determined after performic acid oxidation (33).

c Tryptophan was determined by the method of Pajot (26).

${ }^{d}$ ND, Not determined. 
TABLE 6. Divergence matrix of the $S \Delta_{n} / N$ values for the class I aldolases

\begin{tabular}{|c|c|c|c|c|c|c|}
\hline \multirow[b]{2}{*}{ Strain } & \multicolumn{6}{|c|}{$S \Delta_{n} / N$ values $^{a}$} \\
\hline & S. aureus & $\begin{array}{l}\text { S. epider- } \\
\text { midis }\end{array}$ & S. xylosus & $\begin{array}{c}\text { S. sciuri } \\
\text { subsp. sciuri }\end{array}$ & $\begin{array}{l}\text { S. haemo- } \\
\text { lyticus }\end{array}$ & P. aerogenes \\
\hline $\begin{array}{l}\text { S. aureus ATCC } \\
12600^{\mathrm{T}}\end{array}$ & 0 & 0.106 & 0.222 & 0.273 & 0.121 & 0.548 \\
\hline $\begin{array}{l}\text { S. epidermidis ATCC } \\
14990^{\mathrm{T}}\end{array}$ & 0.106 & 0 & 0.128 & 0.420 & 0.252 & 0.694 \\
\hline S. xylosus DSM $20266^{\mathrm{T}}$ & 0.222 & 0.128 & 0 & 0.303 & 0.325 & 0.856 \\
\hline $\begin{array}{l}\text { S. sciuri subsp. sciuri } \\
\text { ATCC } 29062^{\mathrm{T}}\end{array}$ & 0.273 & 0.420 & 0.303 & 0 & 0.363 & 0.541 \\
\hline $\begin{array}{l}\text { S. haemolyticus DSM } \\
20263^{\mathrm{T}}\end{array}$ & 0.121 & 0.252 & 0.325 & 0.363 & 0 & 0.697 \\
\hline $\begin{array}{l}P . \text { aerogenes ATCC } \\
14963^{b}\end{array}$ & 0.548 & 0.694 & 0.856 & 0.541 & 0.697 & 0 \\
\hline
\end{tabular}

${ }^{a}$ The values were calculated from amino acid compositions by using the method of Cornish-Bowden (4). Values of $<0.42$ indicate that the aldolases are related, values between 0.42 and 0.93 are inconclusive, and values of $>0.93$ indicate that the aldolases are not related.

${ }^{b}$ Data from reference 19.

Staphylococcus capitis, Staphylococcus hominis, and Staphylococcus haemolyticus. In these experiments the IDs varied from 30 to 36 . $S$. hyicus subsp. hyicus and $S$. hyicus subsp. chromogenes had higher IDs (95 to 97). The IDs for the other crude extracts of staphylococci examined were more than 100 . When an $S$. epidermidis aldolase antiserum was used, we obtained IDs similar to those obtained with the $S$. aureus aldolase antiserum. Five strains (strains of $S$. capitis, $S$. hominis, $S$. warneri, $S$. haemolyticus and, to a lesser extent, $S$. aureus) showed low IDs. Again, values obtained with other staphylococci were quite high $(>100)$ and did not allow a clear differentiation of these strains. Antiserum against the $S$. sciuri subsp. sciuri aldolase gave significant cross-reactions with the crude extract of $S$. sciuri subsp. lentus (ID, 67). The IDs for all other staphylococcus strains were more than 100 .

Determination of amino acid compositions and calculation of sequence homology. After hydrolysis of the purified proteins by a new hydrolysis method (36), the amino acid compositions were determined (Table 5). The method which we used generally gives a higher recovery of amino acids than the conventional method (25). All proteins showed similar compositions. The only major difference was the high content of glutamic acid residues in the $S$. sciuri enzyme. The samples were hydrolyzed and analyzed in parallel in order to obtain similar standard deviations for all compositions. The sequence homology of the class I aldolases was calculated from the amino acid compositions of the enzymes by using two independent methods $(4,11)$. The two methods gave comparable results. The values determined by the method of Cornish-Bowden (4) are shown in Table 6. The class I aldolase from Peptococcus aerogenes $(19,20)$ was also included as a control. The $S \Delta_{n} / N$ values for the staphylococcal aldolases are within the optimal range of this method $\left(S \Delta_{n} / N, \leq 0.42\right)$, which allows a clear order of similarity in sequence homology. $S \Delta_{n} / N$ values of 0.42 to 0.93 indicate possible similarity of proteins, but do not allow conclusions as to any specific order of relatedness (4). A peptococcal aldolase having an $S \Delta_{n} / N$ value between 0.541 and 0.856 is obviously related to these proteins even if the $S \Delta_{n} / N$ values are out of the range of high significance (4). When the class I aldolase from $S$. aureus was compared with aldolases from several other organisms (Table 7), the only protein that was

TABLE 7. $S \Delta_{n} / N$ values for aldolases from several organisms compared with the class I aldolase from $S$. aureus

\begin{tabular}{lc}
\hline \multicolumn{1}{c}{ Source of aldolase } & $\begin{array}{c}S \Delta_{n} / N \text { compared with } \\
S . \text { aureus ATCC } \\
12600^{\mathrm{T}} \text { aldolase }\end{array}$ \\
\hline S. aureus ATCC $12600^{\mathrm{T}}$ & 0 \\
$P$. aerogenes ATCC $14963^{b}$ & 0.548 \\
Rabbit muscle $^{c}$ & 1.194 \\
E. coli Crooke strain (class I) $^{d}$ & 1.976 \\
E. coli Crooke strain (class II) & ${ }^{e}$ \\
Yeast (class II) $^{f}$ & 0.810 \\
\hline
\end{tabular}

${ }^{a}$ The values were calculated from amino acid compositions according to the method of Cornish-Bowden (4). Values of $<0.42$ indicate that the aldolases are related, values between 0.42 and 0.93 are inconclusive, and values of $>0.93$ indicate that the aldolases are not related.

$b$ Data from reference 19.

${ }^{c}$ Data from reference 12 .

${ }^{d}$ Data from reference 35 .

e Data from reference 1 .

${ }^{f}$ Data from reference 10 . 


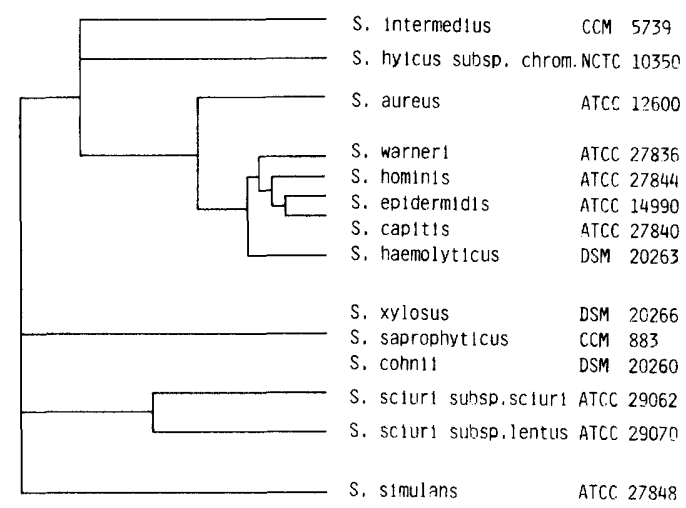

$\underset{100}{1}+1, \frac{1}{50}, 1,1,0$ immunnological distance

FIG. 2. Dendrogram of several staphylococci derived from the IDs of their class I aldolases. The values were determined by the microcomplement fixation method.

highly related was the one from $P$. aerogenes $\left(S \Delta_{n} / N, 0.548\right)$. The class I aldolase from $E$. coli (35) was not related $\left(S \Delta_{n} / N, 1.976\right)$, whereas the class II enzyme from the same organism (1) was moderately related $\left(S \Delta_{n} / N, 0.81\right)$ as was the class II aldolase from yeast $\left(S \Delta_{n} / N, 0.825\right)(10)$. The rabbit muscle aldolase (12) did not show any similarity $\left(S \Delta_{n} / N, 1.194\right)$.

\section{DISCUSSION}

Previously $(8,9)$, it was shown that the class I FDP aldolases from staphylococci appear to be very similar in biochemical properties. After specific labeling of the aldolases with $\left[{ }^{14} \mathrm{C}\right]$ dihydroxyacetone phosphate in crude extracts, the enzymes appeared to be monomeric proteins with molecular weights ranging from 31,000 to 36,000 , as determined by SDS gel electrophoresis (6). These results could be confirmed by using purified proteins.

As shown previously for the $S$. aureus aldolase (8), all purified enzymes used in this study tolerated incubation at a high temperature. The capability to renature to an active form after exposure to a high temperature is a common property of staphylococcal class I FDP aldolases.

Inhibition experiments with several staphylococcal aldolases and antiserum against the $S$. aureus enzyme showed that these aldolases differ in cross-reactivity. More quantitative values for the cross-reactions were obtained by using the microcomplement fixation method. The results were used to derive a dendrogam (Fig. 2). $S$. capitis, $S$. epidermidis, $S$. hominis, $S$. war- neri, and $S$. haemolyticus form a group of highly related species. S. aureus was shown to be closely related to this group, whereas all other staphylococcus strains examined showed distant immunological relationships. The ID of 67 between the FDP aldolases of $S$. sciuri subsp. sciuri and $S$. sciuri subsp. lentus implies a relationship at the species level, as proposed by Kloos (16). If these results are compared with the data from DNA-DNA hybridization studies $(7,17,24,29,32)$ and with the immunological relationships among staphylococcal catalases $(30,32)$, there is a clear concordance.

A comparison of the amino acid compositions of the class I aldolases from $S$. aureus, $S$. epidermidis, Staphylococcus xylosus, S. haemolyticus, and $S$. sciuri was used to derive a second dendrogram (Fig. 3). In contrast to the microcomplement fixation method, all of the values obtained are within the range of high confidence of this method $\left(S \Delta_{n} / N,<0.42\right)$. Figure 3 differs from Fig. 2 in the positions of $S$. xylosus and $S$. haemolyticus relative to $S$. aureus and $S$. epidermidis, but the results are in good agreement with the data from an analysis of $16 \mathrm{~S}$ ribosomal RNAs (23) (Fig. 4).

In the case of the class I aldolases, one gene product and the same enzyme preparation or lysate were compared by using two essentially distinct methods. The microcomplement fixation test gives an indirect measurement of antibody binding to the surface of the enzyme, which is known to be a rather rapidly evolving part of a protein $(3,5,28)$. Although calculation of sequence homology from amino acid composition is empirically derived, it is a direct measurement of the amount of similarity over the whole protein. Analysis of the staphylococcal $16 \mathrm{~S}$ ribosomal RNAs (23) also suggests a close

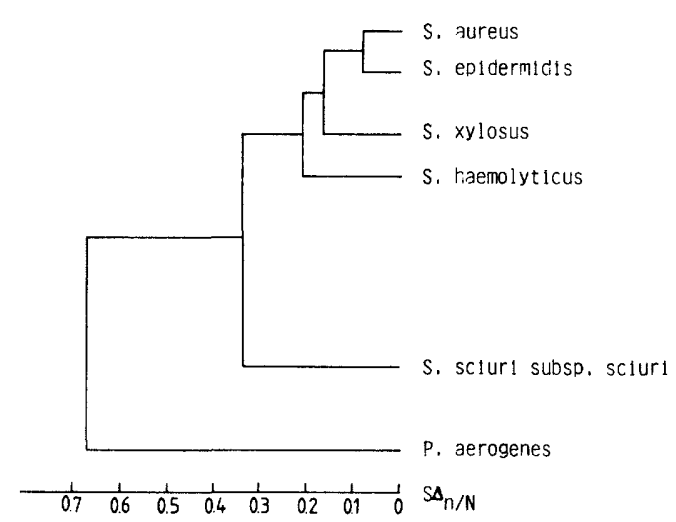

FIG. 3. Dendrogram of several staphylococci and $P$. aerogenes derived from the divergence matrix of amino acid compositions. $S \Delta_{n} / N$ values were determined by the method of Cornish-Bowden (4). 

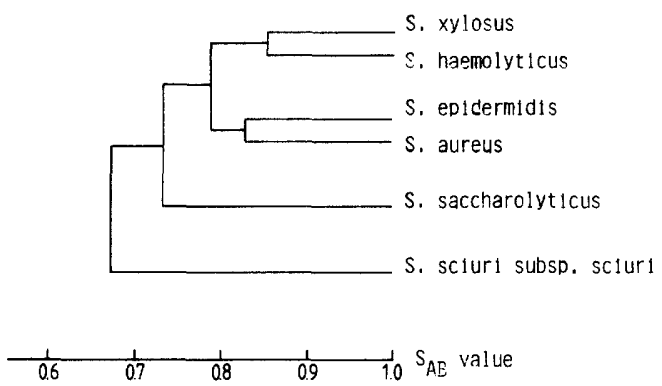

FIG. 4. Dendrogram of several staphylococci determined from a comparison of $16 \mathrm{~S}$ ribosomal RNAs. The data are taken from a study by Ludwig et al. (23). $S_{A B}$, Similarity coefficient.

relationship between $S$. aureus and $S$. epidermidis and even more similarity between $S$. haemolyticus and $S$. xylosus (Fig. 4). These results, however, differ from the results of DNA-DNA homology studies, which show that $S$. haemolyticus is closely related to $S$. epidermidis. Ludwig et al. (23) explained this difference by the occurrence of a highly conserved DNA sequence of the 16S ribosomal RNA cistrons that might not reflect the overall rate of change in the base sequences.

A comparison of amino acid compositions provides a good criterion for determining the phylogenetic relationships among different organisms $(4,11)$. By choosing proteins of a highly conserved structure, it should be possible to compare even rather distantly related organisms. Tests for immunological cross-reactions among aldolases seemed to produce limited resolution of some relationships in the present

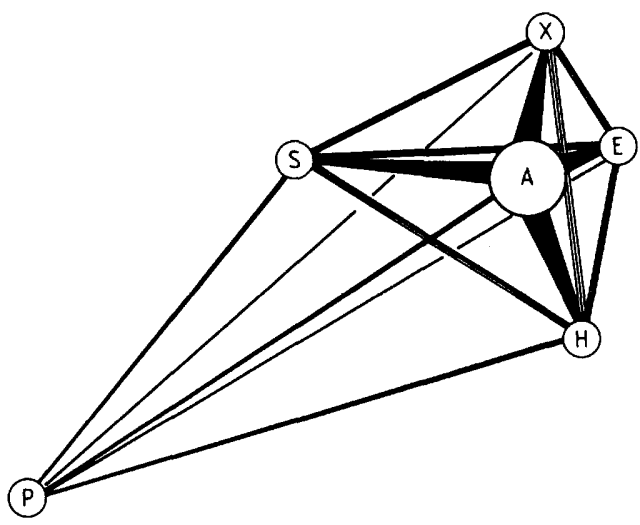

FIG. 5. Projection of the three-dimensional relationships among $S$. aureus (A), $S$. epidermidis $(\mathrm{E}), S$. xylosus (X), S. haemolyticus $(\mathrm{H}), S$. sciuri subsp. sciuri $(\mathrm{S})$, and $P$. aerogenes $(\mathrm{P})$. The distances are proportional to the binary values for $S \Delta_{n} / N$ (see Table 7). study, although cross-reactions occurring with several proteins reflected a similarity in protein sequences $(3,28)$. The obvious advantage of the immunological method is that it also reflects similarities in the tertiary structures of proteins (5).

A dendrogram does not always show the distances of binary values (34). The binary rates in Table 6 show a greater distance between $S$. haemolyticus and $S$. xylosus $\left(S \Delta_{n} / N, 0.325\right)$ than between $S$. aureus and $S$. sciuri $\left(S \Delta_{n} / N, 0.273\right)$. This finding is not visible in the dendrogram (Fig. 3), but such relationships may only be expressed by a three-dimensional figure. A projection of the three-dimensional relationship, as determined from the $S \Delta_{n} / N$ values, is shown in Fig. 5; here the discrepancy mentioned above can be clarified. $S$. sciuri subsp. sciuri still has an isolated position, whereas all other staphylococci form a homogeneous cluster.

\section{ACKNOWLEDGMENTS}

This work was supported by a grant from the Deutsche Forschungsgemeinschaft and by a short-term fellowship from the European Molecular Biology Organization to S.F.

We thank Rudolf van den Broek for the computer calculations of the divergence matrix and J.-J. Scheffler for technical assistance.

\section{LITERATURE CITED}

1. Baldwin, S. A., R. N. Perham, and D. Stribling. 1978. Purification and characterization of the class II D-fructose-1,6-biphosphate aldolase from $E$. coli (Crookes strain). Biochem. J. 169:633-641.

2. Champion, A. B., E. M. Prager, D. Wachter, and A. C. Wilson. 1974. Microcomplement fixation, p. 397-416. In C. A. Wright (ed.), Biochemical and immunological taxonomy of animals-1974. Academic Press, Inc., London.

3. Champion, A. B., K. L. Soderberg, A. C. Wilson, and P. P. Ambler. 1975. Immunological comparison of azurins of known amino acid sequence. J. Mol. Evol. 5:291-305.

4. Cornish-Bowden, A. 1981. Interpretation of amino acid compositions. Trends Biochem. Sci. 6:217-219.

5. Crumpton, M. J. 1974. Protein antigens: the molecular bases of antigenicity and immunogenicity, p. 1-78. In $\mathrm{M}$. Sela (ed.), The antigens, vol. 2. Academic Press, Inc., New York.

6. Fischer, S., H. Luczak, and K. H. Schleifer. 1982. Improved methods for the detection of class I and class II fructose-1,6-bisphosphate aldolases in bacteria. FEMS Microbiol. Lett. 15:103-108.

7. Goodfellow, M., M. Mordarski, A. Tkacz, K. Szyba, and G. Pulverer. 1980. Polynucleotide sequence divergence among some coagulase negative staphylococci. Zentralbl. Bakteriol. Parasitenkd. Infektionskr. Hyg. Abt. 1 Orig. Reihe A 246:10-22.

8. Götz, F., S. Fischer, and K. H. Schleifer. 1980. Purification and characterization of an unusually heat-stable and acid/base stable class I fructose-1,6-bisphosphate aldolase from $S$. aureus. Eur. J. Biochem. 108:295-301.

9. Götz, F., E. Nürnberger, and K. H. Schleifer. 1979. Distribution of class I and class II D-fructose-1,6-bisphosphate aldolases in various staphylococci, peptococci and micrococci. FEMS Microbiol. Lett. 5:253-257.

10. Harris, C. E., R. D. Kobes, D. C. Teller, and W. J. Rutter. 1969. The molecular characteristics of yeast aldolase. Biochemistry 8:2442-2454.

11. Harris, C. E., and D. C. Teller. 1973. Estimation of primary sequence homology from amino acid composition 
of evolutionary related proteins. J. Theor. Biol. 38:347362.

12. Horecker, B. L., O. Tsolas, and C. Y. Lai. 1972. Aldolases, p. 213-258. In P. D. Boyer, (ed.), The enzymes, 3rd ed., vol. 7. Academic Press, Inc., New York.

13. Jayanthi Bai, N., M. Ramachandra Pai, P. Suryanarayana Murthy, and T. A. Venkitasubramanian. 1975. Fructose diphosphate aldolase from Mycobacterium smegmatis. Purification and properties. Arch. Biochem. Biophys. 168:230-234.

14. Kilpper, R., K. Buhl, and K. H. Schleifer. 1980. Nucleic acid homology studies between $P$. saccharolyticus and various anaerobic and facultative anaerobic Gram-positive cocci. FEMS Microbiol. Lett. 8:205-210.

15. Kilpper-Bälz, R., and K. H. Schleifer. 1981. Transfer of Peptococcus saccharolyticus Foubert and Douglas to the genus Staphylococcus: Staphylococcus saccharolyticus (Foubert and Douglas) comb. nov. Zentralbl. Bakteriol. Parasitenkd. Infektionskr. Hyg. Abt. 1 Orig. Reihe C 2:331-334.

16. Kloos, W. E. 1980. Natural populations of the genus Staphylococcus. Annu. Rev. Microbiol. 34:559-592.

17. Kloos, W. E., and J. F. Wolfshohl. 1979. Evidence for deoxyribonucleotide sequence divergence between staphylococci living on human and other primate skin. Curr. Microbiol. 3:167-172.

18. Laemmli, U. K. 1970. Cleavage of structural proteins during the assembly of the head of bacteriophage T4. Nature (London) 227:680-685.

19. Lebherz, H. G., R. A. Bradshaw, and W. J. Rutter. 1973. Structural comparisons between the class I fructose diphosphate aldolases from Micrococcus aerogenes and rabbit. J. Biol. Chem. 248:1660-1665.

20. Lebherz, H. G., and W. J. Rutter. 1973. A class I (Schiffbase) fructose diphosphate aldolase of procaryotic origin. J. Biol. Chem. 248:1650-1659.

21. London, J. 1974. Variations in the quarternary structure of three lactic acid bacteria aldolases. J. Biol. Chem. 249:7977-7983.

22. Lowry, O. H., N. J. Rosebrough, A. L. Farr, and R. J. Randall. 1951. Protein measurement with the Folin phenol reagent. J. Biol. Chem. 193:265-275.

23. Ludwig, W., K. H. Schleifer, G. E. Fox, E. Seewaldt, and E. Stackebrandt. 1981. Phylogenetic analysis of staphylococci, Peptococcus saccharolyticus and Micrococcus mu- cilaginosus. J. Gen. Microbiol. 125:357-366.

24. Meyer, S. A., and K. H. Schleifer. 1978. Deoxyribonucleic acid reassociation in the classification of coagulase-positive staphylococci. Arch. Microbiol. 117:183-188.

25. Moore, S., and H. Stein. 1963. Chromatographic determination of amino acids by the use of automatic recording equipment. Methods Enzymol. 16:819-831.

26. Pajot, P. 1976. Fluorescence of proteins in $6 \mathrm{M}$ guanidine hydrochloride. Eur. J. Biochem. 63:263-269.

27. Penhoe, E., M. Kochmann, and W. J. Rutter. 1969. Molecular and catalytic properties of aldolase C. Biochemistry 8:4396-4402.

28. Prager, E. M., and A. C. Wilson. 1971. The dependence of immunological cross reactivity upon sequence resemblance among lysozymes. I. Microcomplement fixation studies. J. Biol. Chem. 246:5978-5980.

29. Rosenbluhm, E. D., and S. Tyrone. 1979. Deoxyribonucleic acid homologies among staphylococci: coagulase positive reference strains. Curr. Microbiol. 2:171-174.

30. Rupprecht, M., and K. H. Schleifer. 1979. A comparative immunological study of catalases from coagulase positive staphylococci. Arch. Microbiol. 120:53-56.

31. Rutter, W. J. 1964. Evolution of aldolase. Fed. Proc. 23:1248-1257.

32. Schleifer, K. H., S. A. Meyer, and M. Rupprecht. 1979. Relatedness among coagulase-negative staphylococci: deoxyribonucleic acid reassociation and comparative immunological studies. Arch. Microbiol. 122:93-101.

33. Schram, E., S. Moore, and E. J. Bigwood. 1954. Chromatographic determination of cysteine as cysteic acid. Biochem. J. 57:33-41.

34. Stackebrandt, E., B. J. Lewis, and C. R. Woese. 1980. The phylogenetic structures of the coryneform group of bacteria. Zentralbl. Bakteriol. Parasitenkd. Infektionskr. Hyg. Abt. 1 Orig. Reihe C 1:137-149.

35. Stribling, D., and R. N. Perham. 1973. Purification and characterization of two fructose diphosphate aldolases from $E$. coli (Crookes strain). Biochem. J. 131:833-841.

36. Tsugita, A., and J. J. Scheffler. 1982. A new rapid method for acid hydrolysis of protein. Proc. Jpn. Acad. 58(Ser. B): $1-4$.

37. Weber, K., and M. Osborn. 1969. The reliability of molecular weight determination by dodecyl sulphate poly. acrylamide gel electrophoresis. J. Biol. Chem. 244:44064412 . 